\title{
Pemodelan dan Simulasi Medan Listrik pada Jaringan Distribusi 20 kV Double Feeder Konstruksi 3B
}

\author{
Mohamad Ramdan F Herawan ${ }^{1}$, Deny Hamdani ${ }^{2}$, Nanang Hariyanto ${ }^{3}$ \\ ${ }^{1}$ Sekolah Teknik Elektro dan Informatika, ITB, Bandung, Indonesia \\ ${ }^{2}$ Sekolah Teknik Elektro dan Informatika, ITB, Bandung, Indonesia \\ ${ }^{3}$ Sekolah Teknik Elektro dan Informatika, ITB, Bandung, Indonesia \\ Email: ramdanfh@students.itb.ac.id
}

Received 29 May 2020 | Revised 09 July 2020| Accepted 13 August 2020

\begin{abstract}
ABSTRAK
Peralatan listrik yang bertegangan dapat menyebabkan medan listrik di sekitar peralatan listrik, mengetahui besaran nilai medan listrik menjadi hal yang penting, untuk mengetahui paparan medan listrik pada lingkungan sekitar. Metode numerik memainkan peran penting dalam perhitungan medan listrik untuk studi medan listrik yang terkait dengan aplikasi tegangan tinggi. Charge Simulation Method merupakan salah satu metode numerik yang dapat digunakan sebagai pendekatan untuk menghitung distribusi medan listrik dan medan magnet pada penghantar yang bertegangan. Paper ini membahas pemodelan medan listrik di sekitar jaringan distribusi double feeder kontruksi $3 B$ dengan menggunakan Matlab untuk mengetahui jarak ambang batas aman pengaruh medan listrik bagi manusia. Simulasi dilakukan pada setiap fasa konduktor dengan jarak ukuran setiap fasa diatur sesuai kontruksi yang diterapkan pada PLN. Hasil penelitian menunjukan bahwa simulasi menggunakan MATLAB pada distribusi $20 \mathrm{kV}$ double feeder kontruksi 3B, hasil medan listrik maksimal pada ketinggian 1 meter atau pada ketinggian rata-rata manusia, memiliki besaran 1,54 kV/meter. Besaran medan ini lebih kecil dari batas minimal standar WHO dan SNI, sehingga masih masuk batas aman.
\end{abstract}

Kata kunci: medan listrik, charge simulation method, jaringan distribusi, distribusi kontruksi double feeder $3 B$

\begin{abstract}
Electrical equipment can cause an electric field around the equipment, knowing the value of the electric field becomes important, to determine the exposure of the electric field to the surrounding environment. Numerical methods play an important role in the computation of electric fields for the study of electric fields related to high voltage applications. Charge Simulation Method is one of the numerical methods that can be used as an approach to computate the distribution of electric and magnetic fields in a live conductor. This paper discusses the modeling of the electric field around the distribution double feeder $3 B$ construction network using Matlab to determine the safe threshold distance of the influence of the electric field for humans. Simulation experiments are carried out on each phase of the conductor with the distance of each phase adjusted according to the applied construction to PLN. The results showed that the simulation using $M A T L A B$ on the distribution of $20 \mathrm{kV}$ double feeder construction of $3 B$, value of the maximum electric field at an altitude of 1 meter or at an average height of humans, has a magnitude of $1.54 \mathrm{kV} / \mathrm{meter}$. The magnitude of this field is smaller than the minimum WHO and SNI standards, so it is still safe for humans.
\end{abstract}

Keywords: electric field, charge simulation method, distribution network, $3 B$ double feeder construction distribution 


\section{PENDAHULUAN}

Medan listrik adalah fenomena yang terjadi akibat adanya muatan listrik yang terjadi pada suatu ruang di sekitarnya. Daerah yang masih dipengaruhi sifat kelistrikan dari muatan tertentu disebut medan listrik. Di alam medan listrik dihasilkan secara alami oleh pembentukan muatan listrik di atmosfer yang berhubungan dengan petir. Sedangkan medan listrik juga dapat timbul karena adanya peralatan listrik yang bertegangan seperti pada mesin listrik yaitu generator atau motor, lalu pada transformator, ataupun saluran transmisi, dan distribusi listrik. Mengetahui nilai dan besaran medan listrik yang terdapat pada peralatan bertegangan menjadi penting, untuk mengetahui pengaruh dari medan listrik. Secara tidak langsung pengaruh medan listrik dapat menyebabkan masalah terhadap kesehatan manusia. Mengetahui besaran medan listrik dan medan magnet yang masih dalam ambang batas aman jika terpapar ke tubuh manusia dan tidak menimbulkan masalah menjadi suatu hal yang penting. Jika besaran medan listrik dan medan magnet melebihi ambang batas aman dan terjadi secara terus menerus maka akan ada dampak serius bagi kesehatan manusia. Pengaruh medan listrik di sekitar peralatan tegangan tinggi akan jauh lebih besar dari pada pengaruh medan listrik yang ada di alam dikarenakan peralatan listrik akan bekerja secara kontinu dan menimbulkan medan listrik. Permintaan energi listrik dalam jumlah besar akan semakin meningkat seiring dengan pertumbuhan jumlah penduduk yang drastis serta kemajuan teknologi, hal ini akan berdampak pada peningkatan tingkat polusi medan listrik di perkotaan dan lingkungan kerja [1].

Distribusi tenaga listrik dengan beban besar memerlukan tingkat tegangan lebih tinggi untuk penyaluran daya dengan penghantar berukuran lebih kecil. Penggunaan jaringan distribusi listrik bertegangan menengah untuk menyalurkan listrik dekat pelanggan, umumnya berada didaerah padat penduduk, banyak digunakan baik melalui penghantar udara maupun kabel berisolasi. Perkembangan pembangunan wilayah mempertimbangkan kenyamanan dan esensi lingkungan, di mana penggunaan konduktor tegangan tinggi menjadi pilihannya. Penggunaan konduktor menimbulkan permasalahan baru, yaitu medan yang timbul akibat tegangan tinggi di lingkungan sekitar padat penduduk, bahkan medan listrik dan medan magnet yang timbul akan lebih besar apabila penghantar/konduktor tanpa isolasi. Kekhawatiran akan pengaruh buruk medan listrik terhadap kesehatan dipicu oleh publikasi hasil penelitian yang dilakukan oleh Wertheimer dan Leeper pada tahun 1979 di Amerika [2]. Penelitian tersebut menggambarkan adanya hubungan kenaikan risiko kematian akibat kanker pada anak dengan jarak tempat tinggal yang dekat jaringan transmisi listrik tegangan tinggi [2]. Korobkova dkk, (1972), melakukan penelitian terhadap 250 tenaga kerja pada gardu induk $500 \mathrm{kV}$ di Uni Soviet yang terpapar selama 10 tahun dan didapati adanya gangguan susunan syaraf pusat, keluhan nyeri kepala dan gangguan tidur [3] .

WHO pada tahun 1990 telah menentukan standar batasan paparan medan listrik. Batas medan listrik yang diperbolehkan pada masyarakat umum selama 24 jam per hari adalah $5 \mathrm{kV} / \mathrm{m}$. Pemerintah kemudian mengadopsi rekomendasi IRPA dan WHO yang dikutip dalam Standar Nasional Indonesia mengenai batas aman pengaruh medan listrik $50-60 \mathrm{~Hz}$, yang ditunjukkan pada Tabel berikut:

Tabel 1. Ambang batas medan listrik dan medan magnet 50/60 Hz.[4]

\begin{tabular}{ccc}
\hline No & \multicolumn{1}{c}{ Klasifikasi } & $\begin{array}{c}\text { Medan Listrik } \\
(\mathrm{kV} / \mathrm{m})\end{array}$ \\
\hline 1 & $\begin{array}{c}\text { Lingkungan kerja: } \\
\text { - Sepanjang jam kerja }\end{array}$ & 10 \\
& - Waktu Singkat & $30(0 \mathrm{~s} / \mathrm{d} 2$ jam per hari) \\
& - Anggota tubuh (tangan dan kaki) & - \\
\hline 2 & Lingkungan umum: & 5 \\
& - Sampai 24 jam per hari & 10 \\
\hline
\end{tabular}

Ada banyak peralatan listrik bertegangan tinggi yang digunakan dalam sistem tenaga listrik salah satunya adalah saluran yang berupa konduktor atau kawat dan kabel yang menghantarkan listrik. Saluran 
ini bisa terdiri dari saluran transmisi dan distribusi. Distribusi tenaga listrik adalah pengiriman energi listrik dari gardu induk listrik ke lokasi pelanggan listrik. Jaringan distribusi di Indonesia menggunakan arus AC tiga fasa dibagi menjadi distribusi primer dengan tegangan $20 \mathrm{kV}$ yang biasa disebut sebagai penyulang-penyulang / feeders. Sedangkan distribusi sekunder menggunakan tegangan 380V/220V adalah jaringan yang langsung terhubung ke pelanggan. Pada penelitian ini akan membahas paparan medan listrik pada saluran distribusi primer dengan tegangan $20 \mathrm{kV}$. Saluran distribusi ada yang memakai saluran udara dan saluran kabel, karena beberapa pertimbangan salah satunya harga investasinya yang lebih ekonomis maka saluran udara pada jaringan distribusi masih banyak dipilih pada beberapa daerah di Indonesia, dan saluran udara itu biasanya menggunakan kawat tanpa isolasi.

Karena area di sekitar saluran distribusi memiliki medan listrik yang besar, penting untuk menentukan jarak aman dari efek medan listrik bagi kesehatan manusia menurut WHO dan SNI. Paper ini membahas medan listrik yang dihasilkan oleh saluran distribusi $20 \mathrm{kV} 50 \mathrm{~Hz}$, pada semua fasa. Pemodelan medan listrik menggunakan Metode Simulasi Muatan (CSM) yang disimulasikan pada Software Matlab. Tujuannya adalah untuk mengetahui besarnya medan listrik yang dihasilkan oleh saluran distribusi 20 kV $50 \mathrm{~Hz}$, untuk jarak yang aman sesuai dengan standar WHO dan SNI.

\section{TINJAUAN PUSTAKA}

\subsection{Medan Listrik}

Medan listrik merupakan efek yang ditimbulkan oleh adanya muatan listrik (elektron, ion, atau proton) pada ruangan yang ada di sekitarnya. Contoh medan listrik dapat dilihat pada elektroda pelat paralel kapasitor dengan luas S, jarak d, dan muatan +Q dan -Q [5].

Di antara kedua pelat terdapat tegangan listrik $\mathrm{V}_{\mathrm{e}}$ yang dapat diukur dengan voltmeter impedansi tinggi. Tegangan $\mathrm{V}_{\mathrm{e}}$ menghasilkan fluks listrik proporsional $\Psi$ antara elektroda.

$$
\Psi=C \cdot V_{e}
$$

Konstanta proporsionalitas dinyatakan sebagai kapasitansi C. Dari sudut pandang generik C dapat diartikan sebagai konduktansi dielektrik. Di dalam kapasitor terdapat kekuatan medan listrik $E=V_{e} / d$.

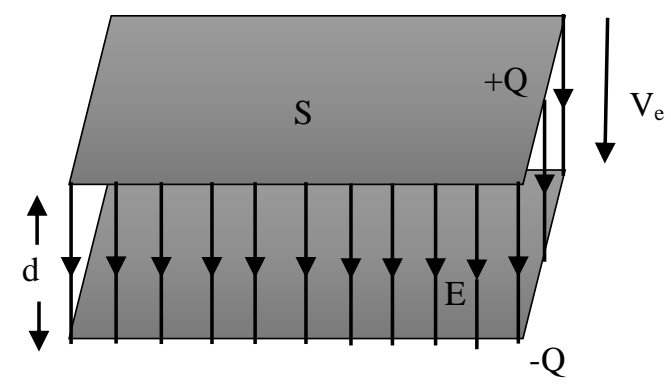

Gambar 1. Medan listrik pada pelat paralel kapasitor ideal [5]

Medan listrik dapat dianalisa seperti medan elektrostatis dan magnetostatis, karena medan listrik yang dihasilkan oleh saluran udara arus bolak-balik adalah kuasi statis [5]. Dalam bentuk kuasi statis medan listrik dihasilkan oleh peralatan listrik dalam keadaan bertegangan. Besarnya medan listrik pada suatu tempat adalah berbanding lurus dengan besarnya tegangan dan berbanding terbalik terhadap jarak.

Kuat medan listrik biasanya disimbolkan sebagai $\mathrm{E} \rightarrow$ dan merupakan vektor yang memiliki besar dan arah tertentu, seperti yang dirumuskan di bawah ini [6]:

$$
\vec{E}=\frac{Q}{4 \pi \varepsilon_{0} R^{2}} \cdot a_{R}
$$


Satuan dari kuat medan listrik $\mathrm{E}^{\rightarrow}$ adalah Volt/meter. Jika digambarkan dalam koordinat kartesian, medan listrik E dari titik yang bermuatan $+\mathrm{Q}$ dan terletak pada koordinat terhadap titik $\mathrm{P}(\mathrm{x}, \mathrm{y}, \mathrm{z})$ akan terlihat sebagai vektor-vektor seperti pada Gambar 2 berikut :

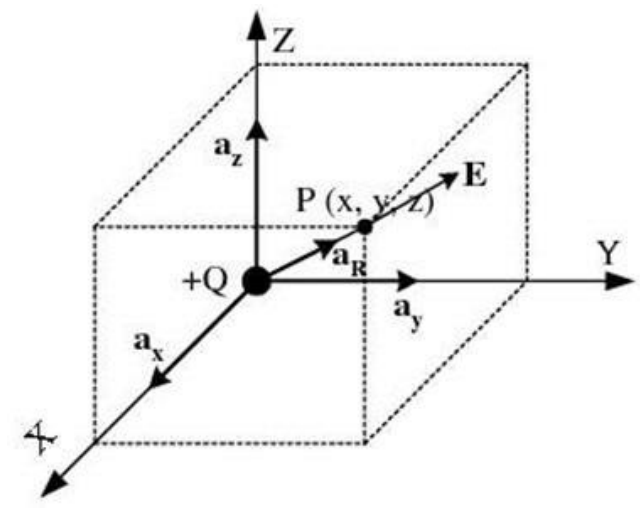

Gambar 2. Titik $P$ merupakan penjumlahan vektor medan listrik akibat muatan $+Q$

Jika ada banyak muatan pada kedudukan yang berbeda-beda, medan yang disebabkan oleh $\mathrm{n}$ muatan titik adalah [7]:

$$
\vec{E}(r)=\frac{Q_{1}}{4 \pi \varepsilon_{o}\left|r-r_{1}\right|^{2}} \cdot a_{1}+\frac{Q_{2}}{4 \pi \varepsilon_{o}\left|r-r_{2}\right|^{2}} \cdot a_{2}+\ldots+\frac{Q_{n}}{4 \pi \varepsilon_{o}\left|r-r_{n}\right|^{2}} \cdot a_{n}
$$

Untuk suatu muatan garis homogen dengan kerapatan muatan per satuan panjang $\rho \mathrm{L}$, maka Persamaan (3) medan listrik di atas akan menjadi:

$$
\vec{E}(\rho)=\frac{\rho_{L}}{2 \pi \varepsilon_{o} \rho} \cdot a_{\rho}
$$

\subsection{Analisis Numerik Medan Elektromagnetik}

Untuk sistem yang sederhana, biasanya dapat dipecahkan dengan solusi analitis. Namun, dalam banyak kasus, sebagian besar aplikasi di dunia nyata sangat kompleks sehingga sangat sulit menggunakan solusi analitis. Dalam kasus seperti itu, metode numerik digunakan untuk perhitungan medan listrik [12].

Menurut Persamaan Maxwell, semua masalah medan elektromagnetik dapat diekspresikan dalam Persamaan diferensial parsial yang tunduk pada kondisi batas tertentu Persamaan diferensial parsial dapat ditransformasikan menjadi Persamaan integral atau Persamaan diferensial-integral. Aspek-aspek penting yang harus diperhatikan dalam metode numerik untuk solusi masalah praktis yaitu, Model matematika yang diekspresikan oleh Persamaan diferensial, Persamaan integral, atau ekspresi variasi disediakan untuk menggambarkan keadaan fisik, lalu model diskritisasi disarankan untuk mendekati domain solusi. sehingga satu set Persamaan aljabar diperoleh. Program komputer dirancang untuk menyelesaikan perhitungan $[13,14]$.

Metode numerik yang umum digunakan adalah Metode Elemen Hingga (FEM), Metode Perbedaan Hingga (FDM), Metode Monte-Carlo (MCM), Metode Charge Simulation (CSM), dan Metode Momen (MoM) [13, 14], metode ini populer karena kemudahannya, fleksibilitas, dan ketersediaan komputer dan perangkat lunak terkait analisis numerik ini [12]. Pemilihan metode numerik tergantung pada sifat aplikasi. Untuk aplikasi tegangan tinggi yang melibatkan masalah batas terbuka, CSM dan MoM biasanya lebih disukai karena metode ini tidak memerlukan diskritisasi wilayah solusi.

\subsection{Charge Simulation Method}

Charge Simulation Method (CSM) atau Metode Simulasi Muatan merupakan suatu metode yang digunakan sebagai pendekatan untuk distribusi medan listrik yang diinduksikan oleh penghantar yang 
bermuatan dengan sekumpulan muatan-muatan diskrit fiktif. Metode ini dianggap sebagai metode yang praktis untuk menghitung medan dan sederhana dilakukan dalam merepresentasikan permukaan ekuipotensial elektroda, aplikasinya tanpa batas, pengaturan yang batasnya meluas hingga tak terbatas dan penentuan langsung ke medan listrik [15]. Konsep dasar CSM adalah dengan mengganti distribusi muatan pada penghantar atau polarisasi muatan pada dielektrik dengan beberapa muatan diskrit fiktif yang nilainya belum diketahui [8].

Besaran muatan diskrit fiktif setara dengan nilai potensial konduktor dan digunakan sebagai referensi untuk menghitung medan listrik di sekitar kontur permukaan konduktor yang dipilih. Setelah nilai dan posisi muatan simulasi diketahui, potensi dan distribusi medan di wilayah tersebut dapat dihitung dengan mudah [8]. Besar muatan diskrit fiktif ekuivalen dengan nilai potensial penghantar yang selanjutnya menjadi acuan untuk menghitung medan listrik di sekitar kontur permukaan penghantar yang dipilih.

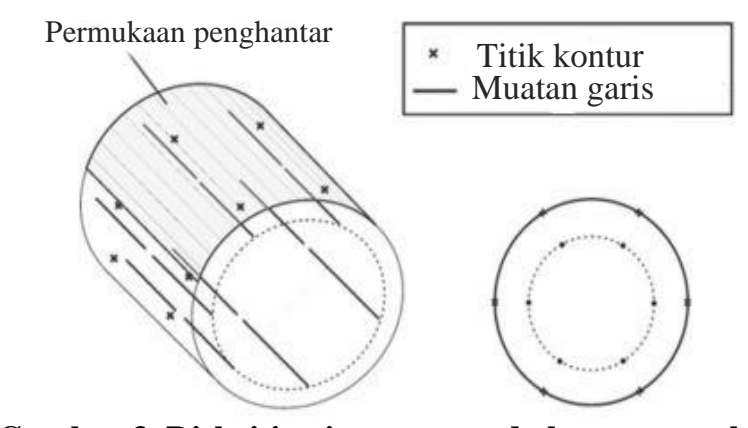

Gambar 3. Diskritisasi muatan pada batang penghantar

Dalam beberapa permasalahan elektrostatis praktis, muatan terletak di dekat suatu konduktor. Sebuah elektron yang baru saja dilepaskan oleh sebuah elektroda dan sebuah jalur transmisi daya yang tergantung di atas bumi konduktor adalah contoh yang lazim ditemui. Kita akan meninjau sebuah kasus sebuah muatan titik di dekat konduktor bidang tak hingga, seperti pada Gambar 4. Dalam menentukan potensial $\mathrm{V}$ pada bagian atas diperlukan penyelesaian Persamaan Poisson dengan $\mathrm{z}>0$, dengan kondisi batas $\mathrm{V}=0$ di $\mathrm{z}=0$ dan di tak hingga [9].

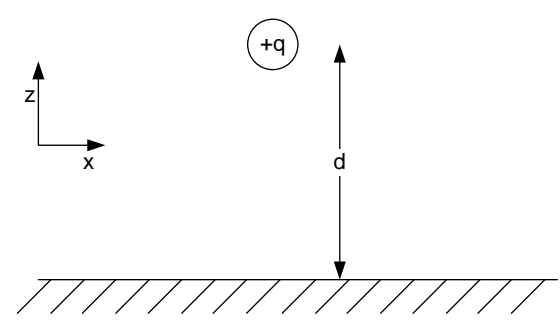

\section{Gambar 4. Muatan titik di dekat konduktor tak hingga}

Karena tidak adanya konduktor, penyelesaian untuk mencari muatan titik di ruang bebas adalah:

$$
V(x, y, z)=\frac{q}{4 \pi \varepsilon}\left(\frac{1}{\sqrt{x^{2}+y^{2}+(z-d)^{2}}}\right)
$$

Fungsi potensial $\mathrm{V}$ pada Persamaan (5) memenuhi Persamaan Poisson untuk z $>0$ dengan kondisi batas $\mathrm{V}=0$. Namun demikian, potensial tersebut tidak sama dengan nol pada $\mathrm{z}=0$. Oleh karena itu, penyelesaian untuk kasus di atas terlihat pada Gambar 5. Potensialnya adalah,

$$
V(x, y, z)=\frac{q}{4 \pi \varepsilon}\left(\frac{1}{\sqrt{x^{2}+y^{2}+(z-d)^{2}}}-\frac{1}{\sqrt{x^{2}+y^{2}+(z+d)^{2}}}\right)
$$


Sehingga didapat potensial elektrostatis dalam daerah $\mathrm{z}>0$ merupakan superposisi potensial muatan titik q dan potensial akibat "bayangan" muatan titik. Begitu fungsi potensial didapat, medan listrik dapat dihitung langsung dari potensial dengan menggunakan Persamaan (6) [9].

$$
E=-\nabla V=\frac{q}{4 \pi \varepsilon}\left(\frac{\hat{x} x+\hat{y} y+\hat{z}(z-d)}{\left(x^{2}+y^{2}+(z-d)^{2}\right)^{3 / 2}}-\frac{\hat{x} x+\hat{y} y+\hat{z}(z-d)}{\left(x^{2}+y^{2}+(z+d)^{2}\right)^{3 / 2}}\right)
$$

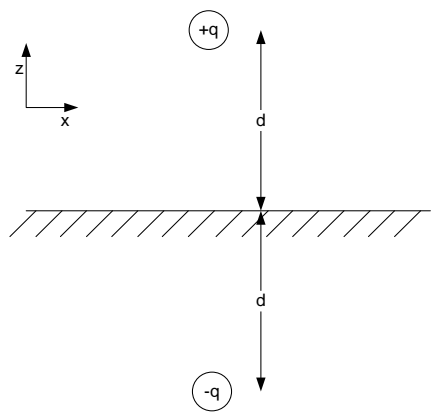

Gambar 5. Muatan titik dan bayangannya

Untuk perhitungan dalam metode CSM Pertama, tetapkan lokasi muatan simulasi $\mathrm{n}$ dan jumlah titik pencocokan yang sama sesuai dengan pengalaman penelitian model aktual, untuk menghitung koefisien potensial [P]. Jadi Persamaan matriks simulasi muatan dihasilkan,

$$
[P] \cdot[Q]=[\varphi]
$$

Di mana, $[\mathrm{P}]$ adalah matriks koefisien potensial; [Q] adalah vektor kolom dengan besaran muatan yang tidak diketahui; $[\varphi]$ adalah vektor kolom dari nilai potensial yang diketahui pada titik kontur. Selesaikan Persamaan (1) dan dapatkan [Q]. Kemudian, [Q] digunakan untuk memverifikasi potensi titik-titik pemeriksaan yang diketahui. Jika hasil verifikasi memenuhi persyaratan, muatan simulasi dapat digunakan untuk menghitung medan listrik [16].

Simulasi muatan bidang 2 dimensi salah satunya dapat dihitung dengan beberapa muatan garis yang digambarkan pada sumbu $\mathrm{x}$ dan $\mathrm{y}$, dengan koefisien muatan garisnya dapat ditulis dengan Persamaan sebagai berikut [10]:

$$
P_{n}=\frac{1}{2 \pi \varepsilon} \ln \sqrt{\frac{\left(x-x_{n}\right)^{2}+\left(y+y_{n}\right)^{2}}{\left(x-x_{n}\right)^{2}+\left(y-y_{n}\right)^{2}}}
$$

dimana $\varepsilon$ adalah permitivitas, $\left(\mathrm{x}_{\mathrm{n}}, \mathrm{y}_{\mathrm{n}}\right)$ koordinat dari $\mathrm{n}$ muatan garis yang membentuk bidang 2 dimensi, dan $(\mathrm{x}, \mathrm{y})$ adalah koordinat titik pengukuran. Dalam teorema Gauss dijelaskan bahwa muatan garis yang terletak pada $\mathrm{y}=0$ (ground), potensialnya adalah nol. Dengan mengatur kondisi batas pada komponenkomponen pada koordinat $\mathrm{x}$ dan y yang membentuk suatu bidang 2 dimensi tersebut, maka medan listrik di sembarang titik akibat $\mathrm{n}$ muatan yang membentuk bidang 2 dimensi dapat dihitung dengan Persamaan sebagai berikut:

Untuk jumlah penghantar $\mathrm{n}$, maka potensialnya masing-masing adalah :

$$
\begin{aligned}
& V_{1}=\frac{\rho_{1}}{2 \pi \varepsilon} \ln \frac{L_{11 \prime}}{L_{11}}+\frac{\rho_{2}}{2 \pi \varepsilon} \ln \frac{L_{12 \prime}}{L_{12}}+\frac{\rho_{3}}{2 \pi \varepsilon} \ln \frac{L_{13 \prime} \prime}{L_{13}}+\ldots+\frac{\rho_{n}}{2 \pi \varepsilon} \ln \frac{L_{1 n \prime}}{L_{1 n}} \\
& V_{2}=\frac{\rho_{1}}{2 \pi \varepsilon} \ln \frac{L_{21 \prime} \prime}{L_{21}}+\frac{\rho_{2}}{2 \pi \varepsilon} \ln \frac{L_{22 \prime}}{L_{22}}+\frac{\rho_{3}}{2 \pi \varepsilon} \ln \frac{L_{23 \prime}}{L_{23}}+\ldots+\frac{\rho_{n}}{2 \pi \varepsilon} \ln \frac{L_{2 n \prime}}{L_{2 n}} \\
& V_{3}=\frac{\rho_{1}}{2 \pi \varepsilon} \ln \frac{L_{31 \prime}}{L_{31}}+\frac{\rho_{2}}{2 \pi \varepsilon} \ln \frac{L_{32 \prime}}{L_{32}}+\frac{\rho_{3}}{2 \pi \varepsilon} \ln \frac{L_{33 \prime}}{L_{33}}+\ldots+\frac{\rho_{n}}{2 \pi \varepsilon} \ln \frac{L_{3 n \prime}}{L_{3 n}} \\
& V_{n}=\frac{\rho_{1}}{2 \pi \varepsilon} \ln \frac{L_{n 1 \prime}}{L_{n 1}}+\frac{\rho_{2}}{2 \pi \varepsilon} \ln \frac{L_{n 2 \prime}}{L_{n 2}}+\frac{\rho_{3}}{2 \pi \varepsilon} \ln \frac{L_{n 3 \prime}}{L_{n 3}}+\ldots+\frac{\rho_{n}}{2 \pi \varepsilon} \ln \frac{L_{n n \prime}}{L_{n n}}
\end{aligned}
$$


Persamaan di atas dapat ditulis dalam bentuk matriks sebagai berikut [17] :

atau:

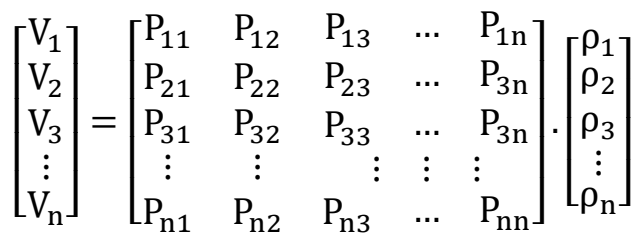

$$
[V]=[P] \cdot[\rho]
$$

Sehingga, muatan garisnya dapat dicari dengan menggunakan Persamaan:

dimana:

$$
[\rho]=[P]^{-1} \cdot[V]
$$

$$
\begin{aligned}
& V=\text { potensial fasa } \\
& P=\text { matriks koefisien maxwell } \\
& \rho=\text { muatan garis }
\end{aligned}
$$

Dalam CSM, simulasi dilakukan yaitu muatan pada permukaan konduktor diganti menggunakan muatan fiktif yang ditempatkan di luar ruang di mana medan dihitung. Jenis muatan fiktif yang paling umum digunakan dalam CSM adalah muatan titik, muatan cincin, muatan garis terbatas, dan muatan garis tak terbatas. Pemilihan muatan fiktif tergantung pada geometri objek yang akan dianalisis. Efek integrasi dari muatan fiktif ini akan mereplikasi efek dari muatan yang ada pada konduktor [12].

Pada saluran distribusi listrik, di mana jumlah konduktor lebih dari satu $(\mathrm{R}, \mathrm{S}, \mathrm{T})$ besarnya potensi pada suatu titik adalah jumlah potensi yang disebabkan oleh konduktornya pada tegangan $20 \mathrm{kV}$.

\section{METODOLOGI}

Spesifikasi jaringan distribusi yang akan disimulasikan pada paper ini adalah jaringan distribusi dengan double feeder atau dua penyulang dengan konstruksi 3B. Tinggi tiang distribusi diasumsikan 9 meter dari tanah hingga mencapai saluran distribusi $20 \mathrm{kV}$ fasa $\mathrm{R}$ dan $\mathrm{T}$, sedangkan jarak antara fasa $\mathrm{R}$ dan $\mathrm{T}$ dengan fasa $\mathrm{S}$ adalah 0,87 meter. Celah di antara fasa $\mathrm{R}$ dengan fasa $\mathrm{T}$ sebesar 0,975 meter. Adapun jarak antara fasa $\mathrm{T}$ feeder 1 dengan fasa $\mathrm{T}$ dari feeder 2 adalah 1,05 meter. Jarak antara fasa $\mathrm{S}$ dengan fasa $\mathrm{T}$ sumbu $\mathrm{x}$ adalah 0,225 meter. Desain dari konstruksi 3B adalah seperti tampak pada Gambar 7 dan Gambar 8 [20].

Simulasi yang dilakukan pada penelitian ini menggunakan software MATLAB R2018a dengan metode Charge Simulation (CSM). Program CSM didesain menggunakan bahasa pemrograman MATLAB yang dikembangkan oleh penyusun melalui implementasi persamaan-persamaan medan pada CSM. Program awal terdiri dari Persamaan medan untuk menghitung nilai dan kontur distribusi potensial dan medan dari beberapa titik ditentukan. Selanjutnya penyusun mengembangkan program di antaranya pembacaan gambar, pengenalan perbedaan material, dan variasi jumlah titik muatan fiktif. Untuk melakukan simulasi dengan CSM itu sendiri melalui beberapa tahap seperti ditunjukan pada diagram alur (flowchart) pada Gambar 6. 


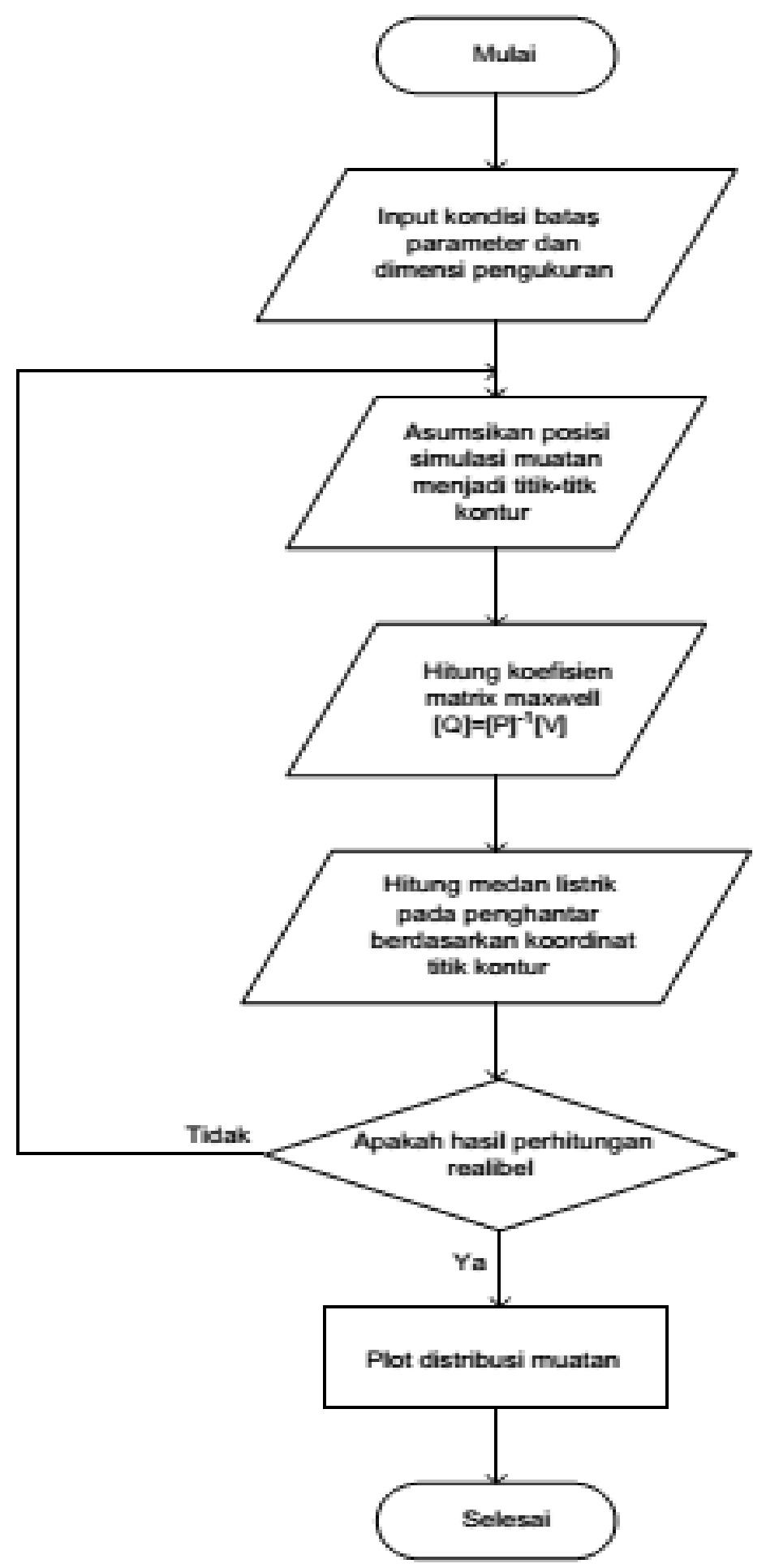

Gambar 6. Diagram Alur Proses Simulasi CSM 


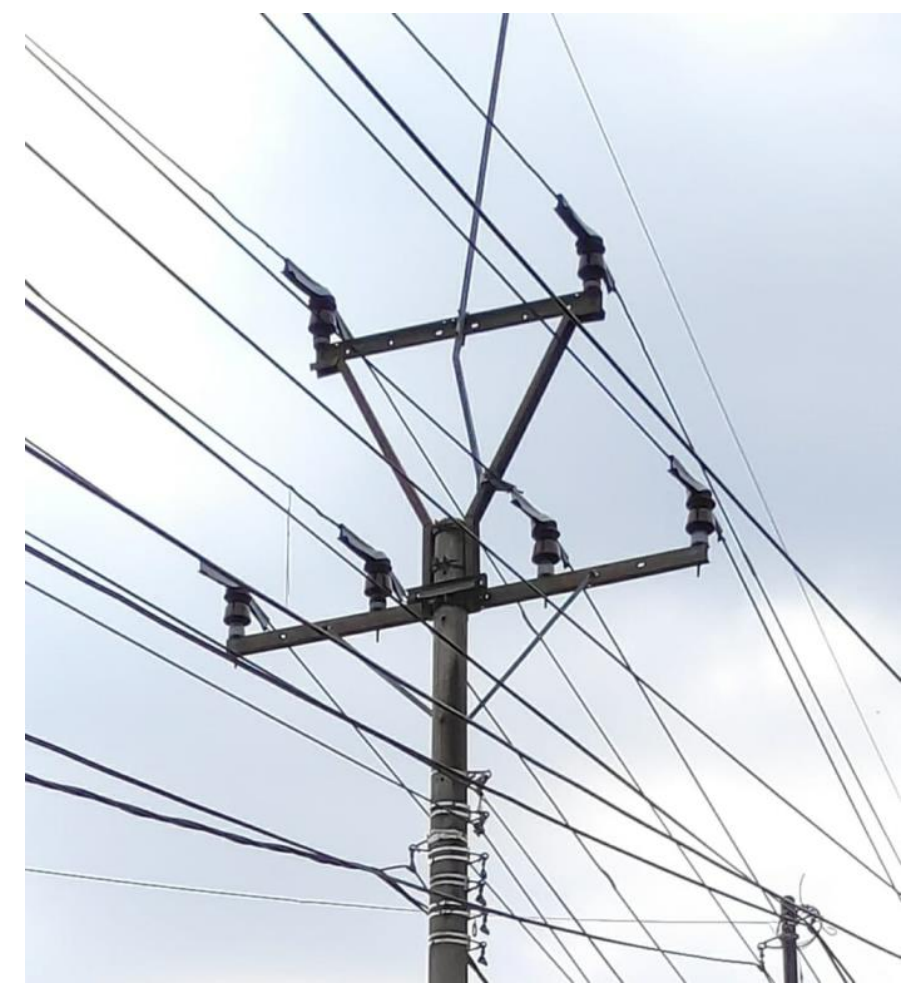

Gambar 7. Foto aktual Kontruksi Double Feeder 3B

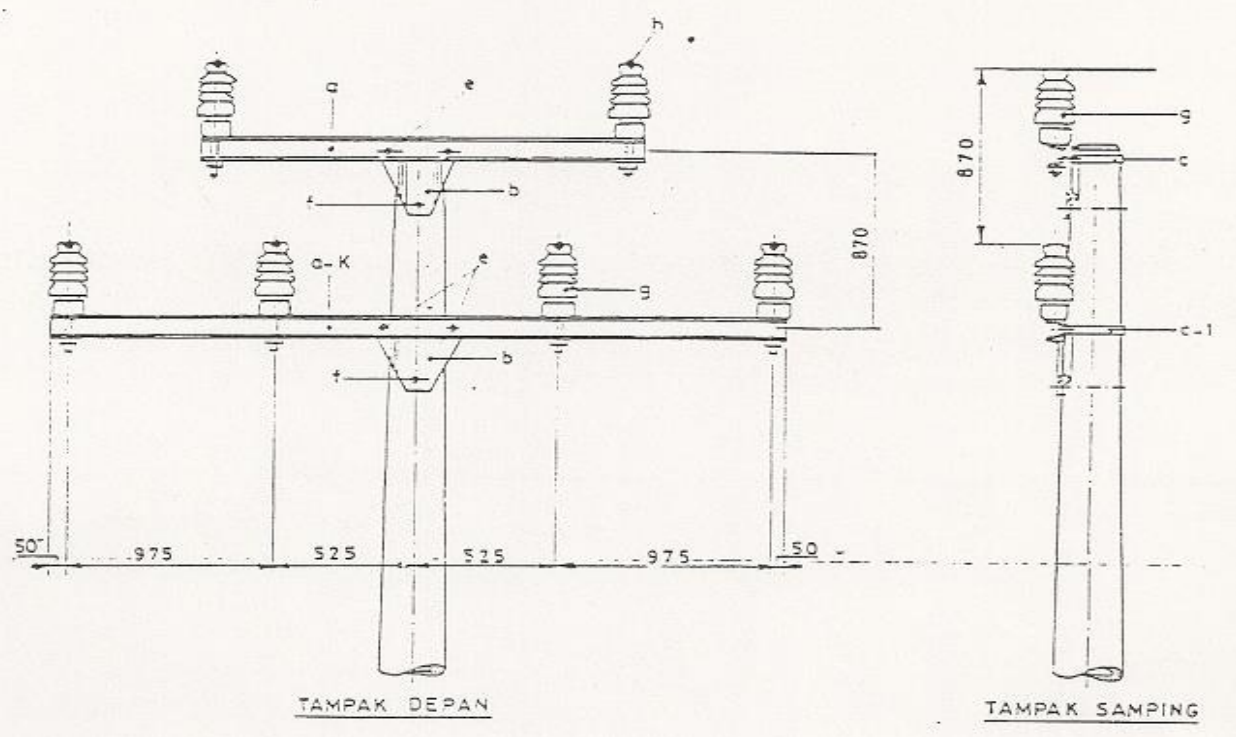

Gambar 8. Foto aktual Kontruksi Double Feeder 3B [20]

Kuat medan listrik dinyatakan dengan arah vertikal dan arah horizontal, masing-masing dengan bagian riil dan imajinernya, atau dengan besar dan sudut fasa waktu.

- Komponen vertikal kuat medan listrik

$$
\mathrm{E}_{\mathrm{y}}=\mathrm{E}_{\mathrm{ry}}+\mathrm{j} \mathrm{E}_{\mathrm{iy}} \quad \text { atau } \quad \mathrm{E}_{\mathrm{y}}=\left|\mathrm{E}_{\mathrm{y}}\right|<\varphi_{\mathrm{ty}}
$$

- Komponen horizontal kuat medan listrik

$$
\mathrm{E}_{\mathrm{x}}=\mathrm{E}_{\mathrm{rx}}+\mathrm{j} \mathrm{E}_{\mathrm{ix}} \quad \text { atau } \quad \mathrm{E}_{\mathrm{x}}=\left|\mathrm{E}_{\mathrm{x}}\right|<\varphi_{\mathrm{tx}}
$$


Persamaan tegangan per-fasanya menjadi :

$$
\begin{aligned}
& V_{R 1}=\frac{V_{01}}{\sqrt{3}} \sqrt{2}\left[\cos 0^{\circ}+j\left(\sin 0^{\circ}\right)\right] \\
& V_{S 1}=\frac{V_{01}}{\sqrt{3}} \sqrt{2}\left[\cos \left(-120^{\circ}\right)+j\left(\sin -120^{\circ}\right)\right] \\
& V_{T 1}=\frac{V_{01}}{\sqrt{3}} \sqrt{2}\left[\cos 120^{\circ}+j\left(\sin 120^{\circ}\right)\right] \\
& V_{R 2}=\frac{V_{01}}{\sqrt{3}} \sqrt{2}\left[\cos 0^{\circ}+j\left(\sin 0^{\circ}\right)\right] \\
& V_{S 2}=\frac{V_{01}}{\sqrt{3}} \sqrt{2}\left[\cos \left(-120^{\circ}\right)+j\left(\sin -120^{\circ}\right)\right] \\
& V_{T 2}=\frac{V_{01}}{\sqrt{3}} \sqrt{2}\left[\cos 120^{\circ}+j\left(\sin 120^{\circ}\right)\right]
\end{aligned}
$$

Kondisi batas ditentukan dengan diskritisasi muatan atau menentukan dan mengatur posisi tata letak titik muatan melalui koordinat $(\mathrm{x}, \mathrm{y})$ pada batas dimensi sistem yang akan diukur. Adanya perbedaan permitivitas akan mempengaruhi besarnya muatan-muatan diskrit di sekitar area pengukuran. Karena permitivitas udara $\left(\varepsilon_{0}\right)$ lebih kecil dari pada permitivitas relatif isolator $\left(\varepsilon_{\mathrm{r}}\right)$, maka tegangan tembusnya akan lebih besar. Sehingga medan listrik di sekitar kawat penghantar akan lebih besar. Karena ada beberapa $\mathrm{n}$ muatan dalam sistem, maka medan listrik seluruh sistem dihitung dengan Persamaan.

Simulasi koordinat $(\mathrm{x}, \mathrm{y})$ yang dilakukan pada analisis ini ditunjukan sebagai berikut:

Koordinat $\mathrm{x}=(-1,5-0,75-0,5251,50,750,525)$.

Koordinat $\mathrm{y}=(99,870999,8709)$

\section{HASIL DAN PEMBAHASAN}

Dari hasil simulasi kita dapat mengetahui beberapa besaran hasil simulasi. Besaran pertama adalah tegangan fasa-ground maksimum pada tegangan saluran $20 \mathrm{kV}$ yaitu sebesar 16,31 Volt pada titik 0 meter dari tanah.

Distribusi potensial dan medan listrik dilihat dari Gambar 9 dan Gambar 10 pada titik sumbu $\mathrm{x}=0 \mathrm{~m}$, dan sumbu $y=9$ meter (tinggi tiang distribusi) terlihat merata pada tinggi (sumbu y) 7 meter hingga 12 meter dan jarak (sumbu x) dari 5 meter di sebelah kiri nol hingga 5 meter di sebelah kanan 0. Untuk distribusi medan listrik (Gambar 10) pada saluran $20 \mathrm{kV}$ antar fasa memiliki medan listrik terbesar dibandingkan dengan daerah lainnya terutama pada antar fasa $\mathrm{R}$ dengan $\mathrm{S}$ dan $\mathrm{T}$ terlihat dari gambar hasil simulasi, nilainya bisa mencapai $7 \mathrm{kV} / \mathrm{m}-11 \mathrm{kV} / \mathrm{m}$.

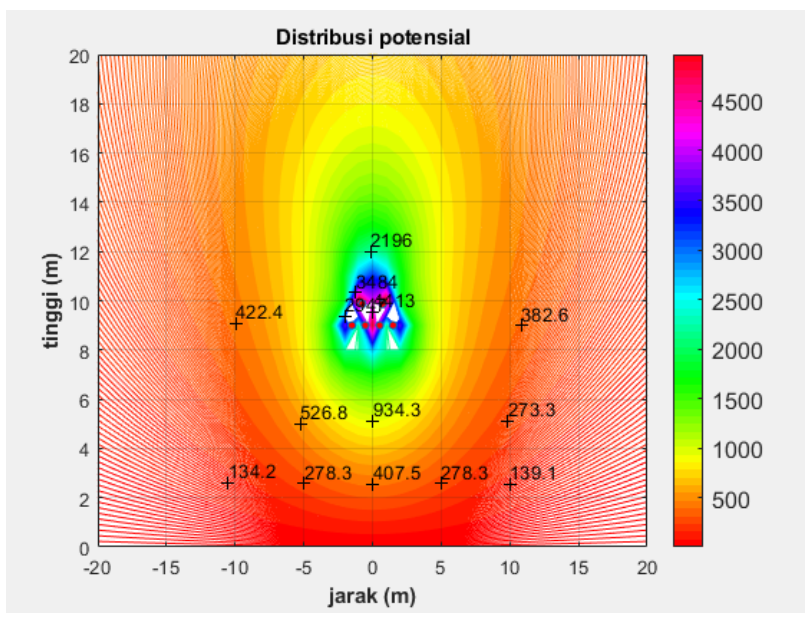

Rekayasa Hijau - 128 


\section{Gambar 9. Distribusi Potensial Listrik (Volt)}

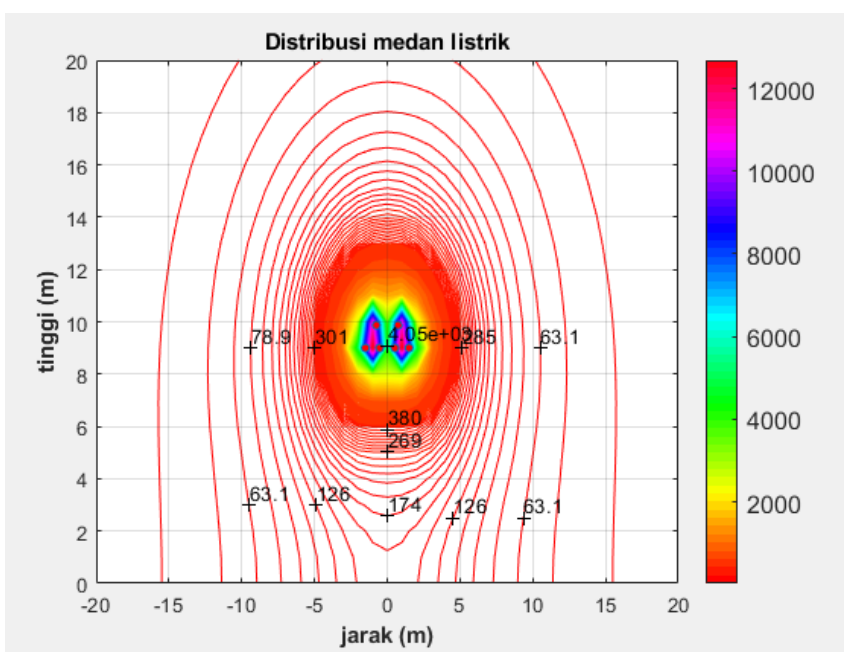

\section{Gambar 10. Distribusi Medan Listrik (Volt/meter)}

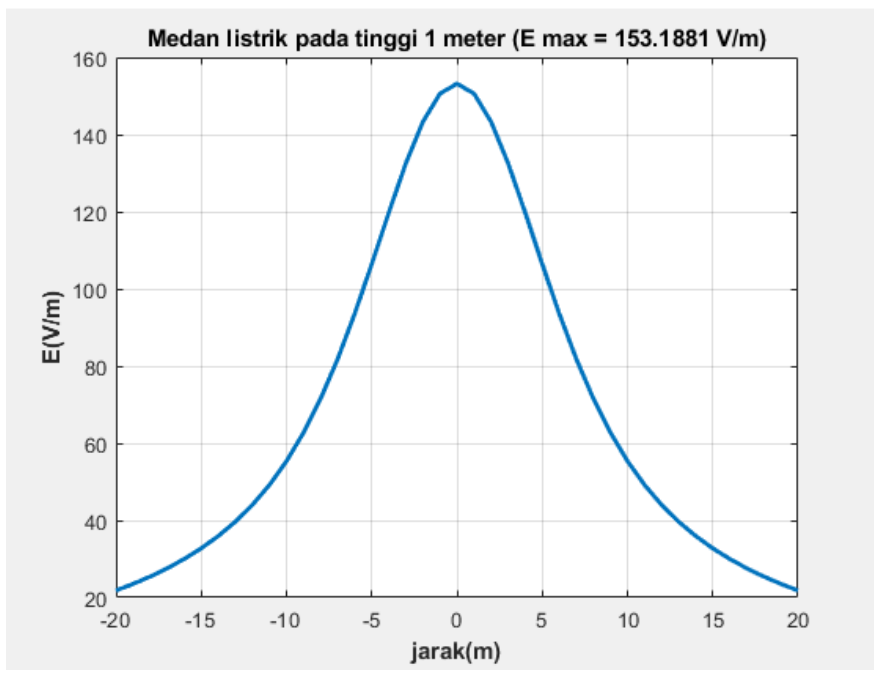

\section{Gambar 11. Sebaran nilai medan listrik dengan jarak}

Dapat dilihat juga pada Gambar 10 ada beberapa titik pada ketinggian 2,5 meter pada titik 0 meter (tepat di bawah tiang) medan magnet sebesar $1,74 \mathrm{kV} /$ meter, sedangkan pada jarak 5 meter dari tiang, besar medan listrik sebesar $1,26 \mathrm{kV} /$ meter. Pada tiang distribusi $20 \mathrm{kV}$ itu sendiri pada ketinggian $9 \mathrm{~m}$ yaitu ketinggian tiang distribusi terhadap tanah, diketahui dari Gambar 10 daerah sekitar konduktor mengindikasikan besar medan listrik yaitu $6-7 \mathrm{kV} /$ meter dan daerah antar konduktor fasa mengindikasikan besar medan $11 \mathrm{kV} /$ meter. Adapun pada jarak Right of Way (RoW) yaitu jarak 2,5 meter dari tanah, medan listriknya sebesar $1,74 \mathrm{kV} / \mathrm{m}$ dan semakin menurun dengan semakin jauhnya jarak titik dari tiang, besaran ini masih masuk dalam kategori aman untuk manusia menurut standar SNI dan WHO. 


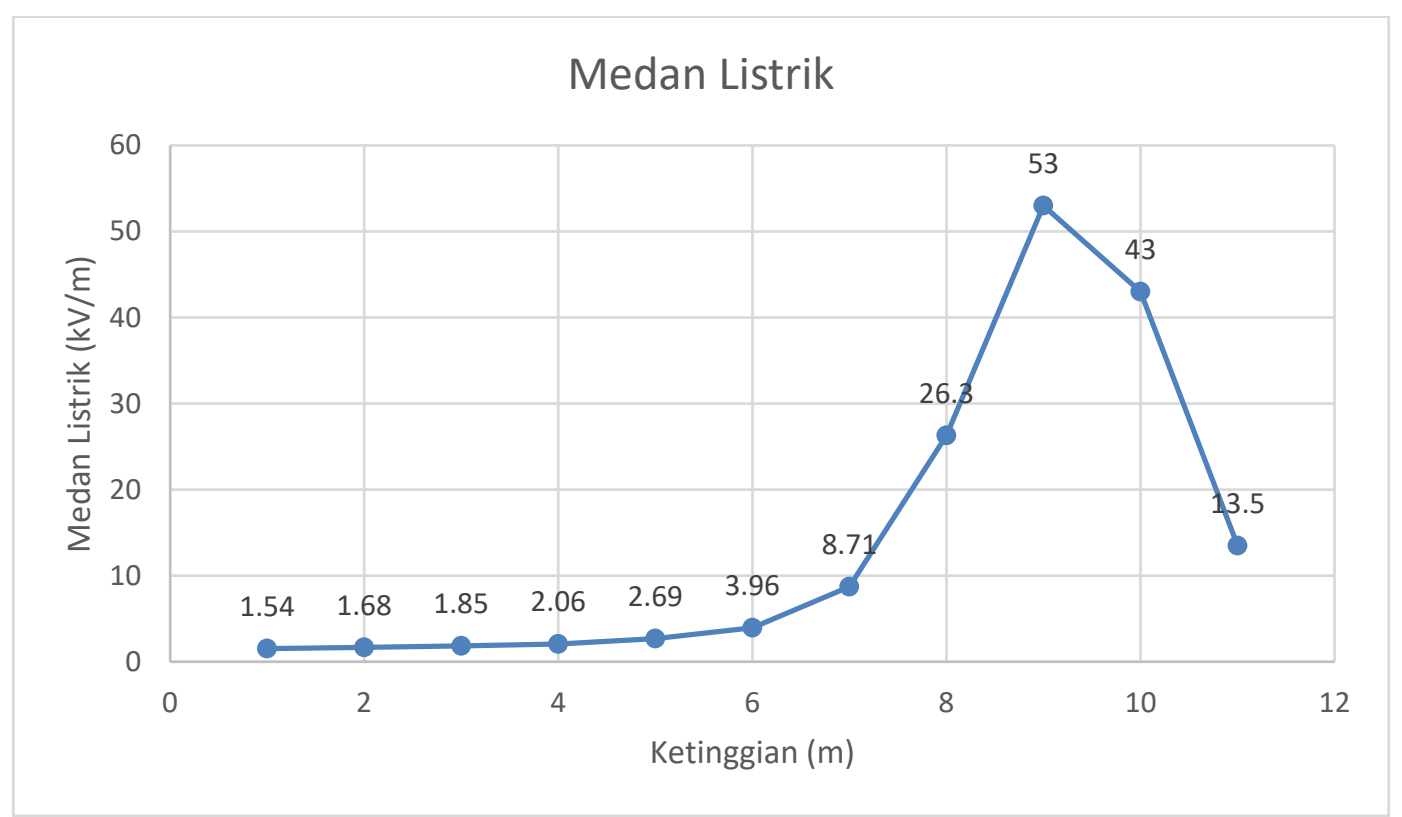

\section{Gambar 12. Kurva nilai medan listrik berdasarkan ketinggian pada jarak 0 meter dari konduktor}

Gambar 12 adalah kurva nilai medan listrik pada jarak 0 meter konduktor (tepat di bawah konduktor), dapat dilihat kurva hasil simulasi medan listrik pada distribusi $20 \mathrm{kV}$ double feeder kontruksi 3B. Terlihat hasil simulasi medan listrik bahwa semakin tinggi objek yang diteliti mendekati konduktor, maka besaran medan listrik akan semakin besar. Nilai medan listrik maksimum terletak pada ketinggian 9 meter, dimana titik itu adalah letak konduktor fasa ( 9 meter dari tanah) dan besaran medan listrik akan semakin berkurang dengan semakin jauh objek dari konduktor (semakin tinggi atau semakin pendek). Sebaran terbesar terjadi pada ketinggian 8 meter dan 10 meter ( -1 meter dan +1 meter dari konduktor), dapat dilihat pada kurva dimana besaran medan listrik melonjak tinggi pada ketinggian 8 meter.

Pada ketinggian 1 meter atau pada rata-rata tinggi manusia di Indonesia, nilai medan listrik yaitu 1,54 $\mathrm{kV} /$ meter. Besaran medan ini lebih kecil dari batas minimal standar WHO dan SNI, sehingga masih masuk batas aman.

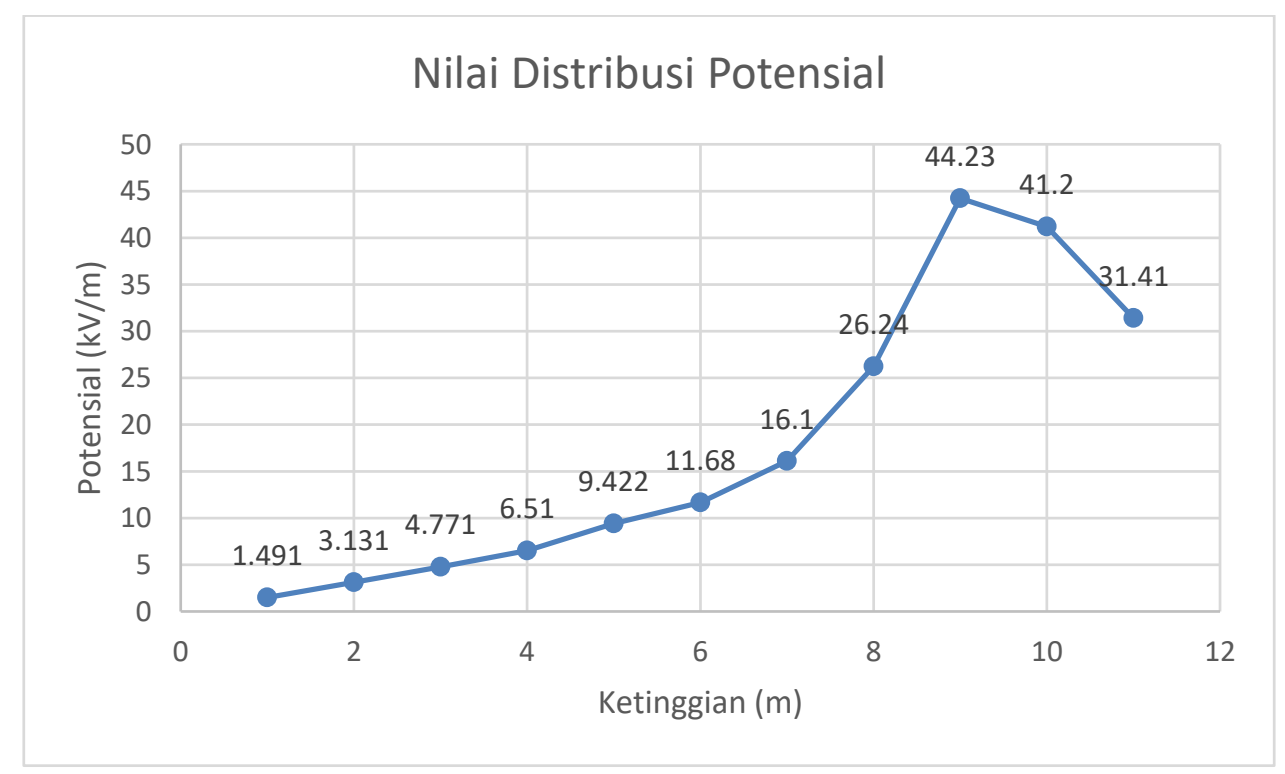

Gambar 13. Kurva nilai potensial berdasarkan ketinggian pada jarak 0 meter dari konduktor 
Gambar 13 adalah kurva nilai potensial pada jarak 0 meter konduktor (tepat di bawah konduktor), dapat dilihat kurva hasil simulasi distribusi potensial pada distribusi $20 \mathrm{kV}$ double feeder kontruksi 3B. Terlihat hasil simulasi medan listrik bahwa semakin tinggi objek yang diteliti mendekati konduktor, maka besaran potensial akan semakin besar. Nilai potensial maksimum terletak pada ketinggian 9 meter, dimana titik itu adalah letak konduktor fasa ( 9 meter dari tanah) dan besaran potensial akan semakin berkurang dengan semakin jauh objek dari konduktor (semakin tinggi atau semakin pendek).

\section{KESIMPULAN}

Metode charge simulation dapat digunakan untuk mengetahui persebaran potensial dan medan listrik pada bidang 2 dimensi. Pada hasil simulasi saluran distribusi $20 \mathrm{kV}$ dengan tinggi $9 \mathrm{~m}$, diketahui bahwa besaran medan listriknya pada titik 9 meter atau tepat di konduktor yaitu sebesar $53 \mathrm{kV} / \mathrm{m}$, dan sebaran nilai medan listrik terbesar berada pada ketinggian 8 meter dan 10 meter dengan nilai medan listrik 26,3 $\mathrm{kV} / \mathrm{m}$ dan $43 \mathrm{kV} / \mathrm{m}$, nilai ini jauh dibatas ambang nilai medan listrik yang dapat diterima oleh manusia sesuai dengan batas WHO pada lingkungan umum yaitu sebesar $5 \mathrm{kV} / \mathrm{m}$, maka ketinggian aman yang masih boleh dijangkau manusia yaitu pada ketinggian maksimum 6 meter dari permukaan tanah atau 3 meter dari konduktor.

Jika melihat besaran nilai medan listrik pada jarak aman atau Right of Way (RoW) yaitu pada ketinggian 2,5 meter dari tanah, besaran medan listriknya $1,74 \mathrm{kV} / \mathrm{m}$ dan akan semakin menurun dengan semakin jauhnya titik dari tiang distribusi $20 \mathrm{kV}$. Pada jarak right of way (ROW) atau jarak aman, besaran medan listrik masih di bawah ambang nilai medan listrik yang dapat diterima oleh manusia sesuai dengan batas WHO pada lingkungan umum, hal ini menunjukan bahwa pada jarak ROW, sebaran dan besaran medan listrik masih dalam batas aman untuk tubuh manusia. Dari hasil simulasi juga dapat disimpulkan jika semakin besar tegangan pada penghantar, maka sebaran potensial dan besaran medan listriknya akan semakin besar, dimana besaran medan listrik pada penghantar dipengaruhi juga oleh tegangan penghantar yang bekerja. Semakin besar tegangan pada penghantar maka kuat medan listriknya juga akan semakin besar.

\section{DAFTAR PUSTAKA}

[1] Dejan M. Petković, Dejan D. Krstić, Vladimir B. Stanković, (2006). "The Effect of Electric Field On Humans In The Immediate Vicinity of $110 \mathrm{KV}$ Power Lines", Working and Living Environmental Protection, 3(1), 63 - 72.

[2] N. Wertheimer and E. Leeper, (1979). "Electrical Wiring Configurations and Childhood Cancer," American Journal of Epidemiology, 109, 273-284.

[3] V. P. Korobkova, (1972). "Influence of the Electric Field in 500 and $750 \mathrm{kV}$ Switchyards on Maintenance Staff and Means for Its Protection" International Conference on Large High Tension Systems, Paris.

[4] Standar Nasional Indonesia, (2002). "Ruang bebas dan jarak bebas minimum Saluran Udara Tegangan Tinggi (SUTT) dan saluran udara Tegangan Ekstra Tinggi (SUTET)", Badan Standarisasi Nasional (BSN), Jakarta.

[5] Adolf J. Schwab, (1988). "Field Theory Concepts", 1st ed. Springer-Verlag Berlin Heidelberg, ISBN-13 : 978-3-642-48943-3.

[6] Hayt, W. H., (1989). "Engineering Electromagnetics", 5th Edition, McGraw-Hill International Book Company, ISBN 0070274061, 31.

[7] Iskander, Magdy F., (1992). "Electromagnetic Fields and Waves". Waveland Press: Illinois.

[8] A. Rankovic, Milan S. Savic, (2010). "Generalized charge simulation method for the calculation of the electric field in high voltage substations", Electrical Engineering, Springer-Verlag, 69-77.

[9] Liang Chi Shen dan Jin Au Kong, (1995) "Aplikasi Elektromagnetik", Jilid kedua". Edisi 3, Erlangga: Jakarta.

[10] Y. Kato, (1980). "A Charge Simulation Method for the Calculation of Two Dimensional Electrostatic Fields", Memoirs of the Fukui Institute of Technology 10, ISSN 0286-8571, 107-117. 
[11] Noviadi Arief R, Agus Risdiyanto, Ade Ramdan, Pemodelan Medan Listrik di Sekitar Area Transformator 3 Phasa, 100 kV/20 kV dengan menggunakan Charge Simulation Method (CSM), Paper LIPI, 1-10.

[12] D. Harimurugan, G. S. Punekar, (2018). "A Comparative Study of Field Computation Methods: Charge Simulation Method and Method of Moments". 2018 International Conference on Power, Signals, Control and Computation (EPSCICON), Thrissur, 1-4.

[13] Pei-bai Zhou, (1993). "Numerical Analysis of Electromagnetic Fields", Springer-Verlag Berlin Heidelberg, ISBN 978-3-642-50321-4.

[14] M. N. O. Sadiku, (2000). "Numerical techniques in electromagnetics", 2. Boca Raton: CRC Press.

[15] S. Salama, S. AbdelSattar, K. O. Shoush, (2012). "Comparing Charge and Current Simulation Method with Boundary Element Method for Grounding System Calculations in Case of MultiLayer Soil”. International Journal of Electrical and Computer Sciences IJECS-IJENS 12 (4).

[16] Y. Wang, Changzhi Lv, (2019). "Electric Field Calculation of the Improved Charge Simulation Method Based on Hybrid Coding". Chinese Automation Congress (CAC).

[17] N. H. Malik, (1989) "A Review of the Charge Simulation Method and its Applications". IEEE Transactions on Electrical Insulation, 24(1), 3-20.

[18] J. C. Salari, A. Mpalantinos, J. I. Silva, (2009). "Comparative Analysis of 2- and 3-D Methods for Computing Electric and Magnetic Fields Generated by Overhead Transmission Lines". IEEE Transactions on Power Delivery, 24(1), 338 - 344.

[19] H Singer, H. Steinbigler P. Weiss, (1974). "A Change Simulation Method for The Calculation of High Voltage Fields", IEEE Transactions on Power Apparatus and Systems, 93, 1660-1668.

[20] PT. PLN (Persero), "Keputusan Direksi PLN No. 475/K/DIR/2010, Tentang Penetapan Kriteria Disain Enjinering Kontruksi Jaringan Distribusi Tenaga Listrik" 11 Agustus 2010. 